\title{
5. 製薬企業はどう考えているのか？教訓をどう生かすのか？
}

$$
\text { 岩㠃甫* 三未修治* 納田 茂* Jonathan Palmer* }
$$

\section{1.はじめに}

2006 年 3 月に発生した TGN1412 事件は, 新規医薬品の 開発に扔いて抗体医薬への比重が増している多くの製薬企 業にとって大きな衝撃をもたらした。ここでは, この事象 が拮抗作用を示す抗体製剂ではなくアゴニスト作用を示す 薬剤で発生したこと, 種差のため動物実験系では十分に探 索できえないか, またはヒトの反応系が存在しない可能性 もあることなどが指摘され，生物学的製剤の初めてのヒト への投与に際して適切な初回投与量の設定や投与の方法に ついてさまざまな課題を与える事例となった.

本稿では, この事象の発生のメカニズムを薬理学的に検 討することにより，生物学的製剤の開発に扔けるヒトへの 初回投与量の設定に対する私共の考え方を報告し，今回の TGN 事件から何を学ぶべきかについて述べる.

\section{2 . 生物学的製剂の特殊性をどう考えるか?}

生物学的製剤（バイオ医薬品）は，治療のターゲットに 対して特異的に機能を発揮することから，より有効で副作 用が少ない治療薬としての期待が大きく, 近年, その開発 作業が活発に行われている。 しかし，その物性や体内動態 の特徵から, 従来の医薬品開発のほとんどを占めていた低 分子化合物との間に多くの差異が認められており，その開 発に際しては生物学的製剤の特徵を理解することが求めら れる。

一般的に蛋白質製剂などを代表とする生物学的製剤は親 水性と疎水性双方の性質を有する高分子化合物である。 そ のため他のコンパートメントへの取込みは難しく, 薬物動 態も低分子化合物とは異なることが多く, 薬力学効果は持 続する傾向がある. また, 生物学的製郕に対して生体が免 疫応答を仕掛ける可能性もあり, 効果の中和や特異的な有 害な反応に対しても注意が必要となる ${ }^{1)}$.

\section{3. 生物学的製剂における「薬物一受容体相互作用」に ついてどう考えるか?}

通常, 薬物の作用は生体の受容体との結合によって発現 し，時として治療効果のみならず望ましくない結果として 生体に有害な反応もみられる。受容体との結合には，活性 を高めて反応を引き起こすアゴニストと, 逆に生体の反応 を阻害するアンタゴニストとがある．多くの例で，アンタ ゴニストでは受容体の $80 \%$ 以上が結合することにより有 意義な阻害効果が生じ，対照的にアゴニストでは受容体の 5\%から 10\%に結合すれば反応が生じることが知られてい

* グラクソ・スミスクライン株式会社 開発本部・臨床薬理部 干 151-8566 東京都渋谷区千駄谷 4-6-15 GSK ビル
る.したがって，薬物の反応を予測するうえでは，薬物の 作用機序と受容体と結合する割合，すなわち受容体占有率

（Ro）を理解しておくことが重要となる.

受容体占有率の算出には複雑な過程が必要であるが, こ こでは, 投与量がどの程度の受容体占有率, また受容体阻 害率となるか，単純に推測する方法を紹介する。

投与する生物学的製剤の最高血中濃度 $\left(\mathrm{C}_{\max }\right)$ とその薬 物の解離定数 $\left(\mathrm{K}_{\mathrm{d}}\right)$ の比, $\mathrm{C}_{\max } / \mathrm{K}_{\mathrm{d}}$ を X とすると, 阻害率は $\mathrm{X} /(1+\mathrm{X})$ で表される． $\mathrm{K}_{\mathrm{d}}$ は Biacore によって測定が可能 であり， $\mathrm{C}_{\max }$ は霊長類の薬物動態データから, Allometric scaling を用いてヒトの PK を推測し, 点滴など投与条件を 加味して計算することができる．たとえば， $\mathrm{C}_{\max } / \mathrm{K}_{\mathrm{d}}=4$ と される場合の阻害率を計算すると, $4 /(1+4)=0.8$ であり, 阻害率は $80 \%$ となる。この $80 \%$ という阻害率すなわち受 容体占有率はアンタゴニストにおいてはその効果を発揮す ることが期待できるレベルであるが，アゴニストにおいて は受容体の活性がほとんど最大に近く示されるレベルとな り，重大な反応が起こることが容易に推測される.

\section{TGN1412 の場合では, どうであったか?}

TGN1412 は TcR を介することなく T 細胞の活性化を もたらすことから superagonist と呼ばれる CD28 に対す るモノクローナル抗体であり, leukemia などさまざまな 疾患に対して, その効果が期待された生物学的製剤であっ た.

この生物学的製剤のヒトへの最初の投与試験（first time in human study：FTIH Study）おける初回投与量の設定に 際しては，まずカニクイザル，アアカゲザルの霊長類の動物 実験の結果から, $50 \mathrm{mg} / \mathrm{kg} /$ week が十分な忍容性を示す 投与量として選択され, 無毒性量 (no observed adverse effect level : NOAEL) は $50 \mathrm{mg} / \mathrm{kg}$ と設定された. 次に FDA のガイドラインに添った形でアロメトリック調整と して $3: 1$ が選ばれ, human equivalent dose $(\mathrm{HED})=16$ $\mathrm{mg} / \mathrm{kg}$ とされた。ここでHED に対しデフォルトの安全 性係数 10 を考虑して maximum recommended starting dose（MRSD）は $1.6 \mathrm{mg}$ と設定され，さらに安全性を考虑 して最終的に初回投与量として $0.1 \mathrm{mg} / \mathrm{kg}$ が決定されて いる ${ }^{2)}$. その結果, サイトカイン・ストームと呼ばれる重 篤な結果がもたらされたが,この $0.1 \mathrm{mg} / \mathrm{kg}$ が受容体占 有率からみるとどの程度となっていたのであろうか?

ここでは, TeGenero 社のデータに基づいて, 先の簡略 法を用いて受容体占有率を計算してみる. TGN1412 の解 離定数は, TGN1412 の治験薬概要書によれば $1.88 \mathrm{nM}$ で あり，カニクイザルを用いたでの初回 $5 \mathrm{mg} / \mathrm{kg}$ 投与での 
$\mathrm{C}_{\max }$ の值から, $0.1 \mathrm{mg} / \mathrm{kg}$ 投与では $\mathrm{C}_{\max } / \mathrm{K}_{\mathrm{d}}$ の值はおよそ 5 となる。この時, 動物実験では 1 時間の持続静注で投与さ れているのに対して, FTIH 試験では計算上 3 分間ほどで 投与が終了している ${ }^{3)}$.このことを考慮すれば， $\mathrm{C}_{\max } / \mathrm{K}_{\mathrm{d}}$ は おそらく10 近いかそれ以上となったものと推測され, Fig. から Ro は $90 \%$ 以上となる. Duff らによる最終報告にお いても, Roは $90.6 \%$ と推定されている21.

いずれにしても, 従来の毒性学的観点からの算定方法で は十分に安全と考えられた TGN1412の $0.1 \mathrm{mg} / \mathrm{kg}$ とい う初回投与量は受容体占有率の観点からは，90\%という大 変に高いレベルの数字であることが判る，先に述べたよう に,この $90 \%$ という占有率はアンタゴニストであればその 効果を発揮するためには許容される值であるが, この生物 学的製剤がアゴニストであることを考えれば，この薬物が 受容体と結合してその活性を最大限に高めたことが容易に 推測でき, サイトカイン・ストームが発生したのも当然の 結果であることが理解できる.

\section{5.この事件を受けて，ではどうすればよいか?}

TGN の試験計画書によれば，投与スケジュールは， 0.1 $\mathrm{mg} / \mathrm{kg}, 0.5 \mathrm{mg} / \mathrm{kg}, 2 \mathrm{mg} / \mathrm{kg}, 5 \mathrm{mg} / \mathrm{kg}$ となっており, 受 容体占有率はそれぞれ $90 \% ， 98 \% ， 99 \% ， 100 \%$ と計算さ れ，現時点ではアゴニスト製凨の FTIH 試験としてはとう てい許容できない投与量であったことが判る. Fig. から 判断すると, 占有率が $10 \%$ 程度であれば, 発現する活性も 低いことが予想され，現在では生物学的製剂の初回投与量 は受容体占有率の面からは $10 \%$ が選択される傾向にある。 今回の場合では，初期投与量を $0.1 \mathrm{mg}$ の $1 / 100$ の 0.001 $\mathrm{mg}$ とすることによって, $\mathrm{C}_{\max }$ は $0.023 \mathrm{ug} / \mathrm{mL}$ となり, $\mathrm{C}_{\max } /$ $\mathrm{K}_{\mathrm{d}}$ は 0.08 と計算され, Ro は $8 \%$ となり, 初回投与量とし ては $0.001 \mathrm{mg} / \mathrm{kg}$ は妥当な值と思われる.

ここでは， $\mathrm{C}_{\max }$ は動物実験のデータからモデリングに よってヒトに拈ける值が予測されたが，次に述べる近似的 な薬理学的法則は，算出された投与量が妥当かどうかを知 る簡便な方法であり，有用と思われる。

アゴニスト : first dose $=\mathrm{K}_{\mathrm{d}} / 2000$ これで Ro $<10 \sim 50 \%$

アンタゴニスト : first dose $=\mathrm{K}_{\mathrm{d}} / 100$ これで Ro $>80$ $90 \%$

この法則を今回の事件での投与量 $0.1 \mathrm{mg}$ を当てはめて みると $\mathrm{K}_{\mathrm{d}} / 18.8$ での計算の結果であることが判り, 法則ど おりに $\mathrm{K}_{\mathrm{d}} / 2000$ で計算すると，およそ $0.001 \mathrm{mg}$ となり，

先ほど Ro：10\%として計算された值となる。おおよその 検討をつけるためには便利な方法であることが判る。

また, 初回投与量の設定方法として, 従来毒性学的な検 討から用いられてきた NOAELやNOELに変わって, 今 回, 薬理学的観点からの検討も加味した minimal anticipated biological effect level（MABEL）が提唱されている. この方法は in vitro や in vivo を問わず，すべての基礎実験 や動物実験の結果を薬理学的にも詳細に検討することで初 回投与量を設定する方法である。この MABEL は，算定

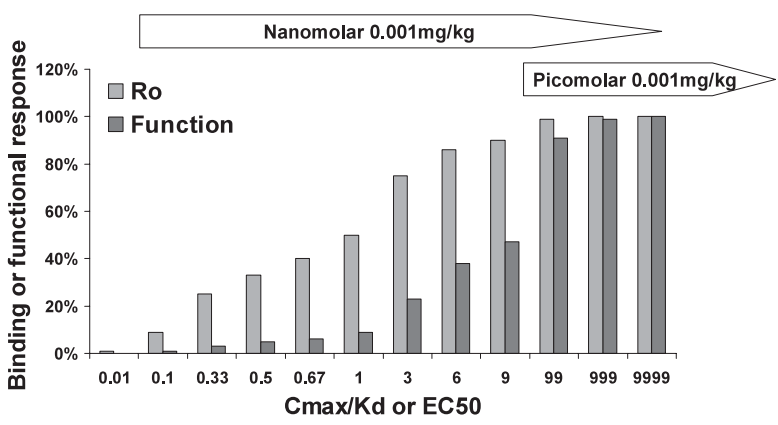

Fig. 薬物の反応と受容体占有率 $(\mathrm{Ro})$ との関係

の基準として用いる非臨床試験によって投与量が異なるこ とも予想され，算出方法の体系化が必要であるが， CPMP のガイドラインにも推奨されている方法であり ${ }^{4)}$ ，今後は 生物学的製剂を含めてすべての医薬品候補品のヒトへの最 初の臨床試験において，その初回投与量を算定する基準と なっていくものと思われる，ただ，以前にもげっ歯類での 実験結果を詳細に検討して $0.1 \mathrm{mg}$ が初回投与量としては 高すぎる值であることを指摘している報告もあり ${ }^{5)}$, 生物 学的製剂においても種の違いから来る制限はあるものの, 動物実験の結果は臨床開発に扔ける重要な情報を提供して いることを改めて認識する必要があるものと考えられる.

\section{6. まとめ}

今回の TGN1412 事件によって, 生物学的製剤のヒトへ の初回の投与に当たっては, 対象薬物の毒性学的な検討の みならず, 薬理学的・薬理作用のより深い理解と洞察が必 要なことが示された．とくに受容体への薬物の結合率の理 解とアンタゴニストとアゴニストなど作用機序の理解に基 づいた初回投与量の設定が必要である.

今後の医薬品開発においては新規なメカニズムを特徵と する薬剤が多く登場してくることは想像に難くない。 その 際には過度に慎重になりすぎずに，臨床試験の科学性と並 んで被験者の保護などの倫理的な面も厳格に検討して安全 性を十分に確保しながら開発を進める必要があろう。日本 がこのような医薬品の開発に FTIH 試験から参加するた めには, この領域の臨床薬理の専門家の養成と施設の充実 が急がれる.

\section{文献}

1）Simon JB, Gorden DE. 薬物一受容体相互作用, 病態生理に基づ く臨床薬理学. メディカル・サイエンス・インターナショナル, 2006.

2) Expert Scientific Group on Phase One Clinical Trials-Final Report, 30th November 2006. http://www.tsoshop.co.uk

3）小林 潔. 臨床評価 $2006 ; 34$ (Suppl XXIV)：81.

4) Guideline on Strategies to Identify and Mitigate Risks for ForstIn-Human Clinical Trials with Investigational Medicinal Products. 19 July, 2007. http://www.emea.europa.eu

5) 浜 六郎. 臨床評価 $2006 ; 34$ (Suppl XXIV)：171. 